\title{
PROMOVER A DIVULGAÇÃO CIENTÍFICA DA PSICOLOGIA: OS ENCONTROS COM A PSICOLOGIA NA LIVRARIA BARATA
}

\author{
Maria Luísa Pedroso de Lima ${ }^{1}$
}

A divulgação da ciência não é uma actividade nova. Desde o século XVIII que os estudos da ciência e os seus resultados serviam para entreter os nobres em sessões palacianas ou para espantar o povo em espectáculos de rua. O que há de novo na actual perspectiva sobre a divulgação da ciência é que não se pretende com ela demonstrar a enorme diferença entre os detentores do conhecimento científico e os cidadãos leigos, como acontecia então, mas mostrar que todos podemos compreender e utilizar, no quotidiano, os resultados da investigação produzida nas diversas áreas científicas. Nesse sentido, assistimos nos últimos anos a um grande esforço ao nível das ciências exactas, naturais e da engenharia no sentido de divulgarem, em linguagem acessível, as suas descobertas e de envolverem os cidadãos em geral, e os jovens em particular, em actividades lúdicas e de contacto mais informal com a ciência. A abertura de museus de ciência dedicados a jovens, ou as olimpíadas de física ou matemática, são disso exemplos claros.

$\mathrm{Na}$ psicologia, como noutras ciências sociais e humanas, esta temdência não é tão visível. Apesar do grande aumento da investigação produzida e publicada na nossa, a visibilidade do que fazemos junto do grande público é muito pequena. Isto é, a investigação que produzimos, que é cada vez mais e de melhor qualidade, fica fechada nos circuitos das comunicações a congressos, dos working-papers que discutimos com colegas e alunos e das publicações em revistas científicas especializadas. E este fechamento da investigação em Psicologia sobre si própria tem como consequência a desvalorização da divulgação científica. Os receptores privilegiados da comunicação dos investigadores em psicologia são os outros investigadores (ou os aprendizes de investigadores, que são os estudantes universitários de psicologia). Os cidadãos não psicólogos, que têm uma enorme apetência para saber mais sobre o comportamento humano, não são normalmente considerados como um alvo a atingir.

Para ajudar a inverter esta tendência, a Associação Portuguesa de Psicologia e a Livraria Barata resolveram promover encontros de divulga-

\footnotetext{
${ }^{1}$ Instituto Superior de Ciências do Trabalho e da Empresa PSICOLOGIA, Vol. XIX (1-2), 2005, Edições Colibri, Lisboa, pp. 265-266
} 
ção científica. O desafio que fizemos aos investigadores foi o de conseguirem falar do seu trabalho numa linguagem mais simples que pudesse ser acessível ao cidadão comum. Que conversassem com as pessoas, em vez de darem aulas. $\mathrm{O}$ convite que fizemos às pessoas foi o de virem passar $\mathrm{o}$ fim da tarde à Livraria Barata da Avenida de Roma onde, entre livros e quadros, a Dr ${ }^{\mathrm{a}}$ Graça Didier proporcionou um espaço agradável para podermos todos conversar sobre temas da Psicologia. É o resumo de um destes encontros que publicamos agora. Esperemos que fiquem com vontade de vir participar nos próximos "Encontros com a Psicologia". 